\title{
Development of Environmental-Based Indonesian Teaching Materials
}

\author{
By: \\ Margiani \\ Padang State University \\ Email: margiani22pku@gmail.com
}

Industrial Revolution Era 4.0. have a complex and comprehensive impact on human life. Including in the realm of education. This era allows for disruption in many fields, without exception also occurring in the field of education. This has implications for the emergence of various challenges in learning. Furthermore, Mulyadi, et al. (2019) states that a teacher or lecturer is also required to be careful in choosing and applying teaching methods that are in accordance with the objectives to be achieved, as well as being able to choose media that is appropriate to the material that will facilitate the delivery of material. Currently, teachers are required to be able to provide the skills needed by their students. Therefore, it takes a teacher who has high motivation to continue learning to improve his quality by learning new knowledge and knowledge, is open to new things, adaptive to change, responds responsively and quickly to new information and is accommodating to student needs., and creative in developing learning media and teaching materials, both in terms of providing teaching materials, according to Mulyad, et al. (2019) multimedia provides opportunities for educators to develop learning techniques and also produce maximum results. To achieve learning objectives, educators need to understand learning techniques that are useful in the teaching and learning process.

Vivi, et al. (2019) explains that language learning is the foundation on which other academic skills are built. Environmentally-based Indonesian teaching materials are a must in preserving and protecting the environment and the ecosystem of living creatures that are able to contribute to the sustainability of a balanced and more harmonious life. In addition, environmental education materials can be an alternative choice to be applied to students so that they are able to develop a mindset and act, behave physically and mentally in daily life. Novelt, et al. (2018) suggests that the purpose of learning Indonesian is to cover cognitive (knowledge), psychomotor (skills), and affective (attitudes and values) development. In the learning process, students play an active, creative, critical role, and gain direct experience so that learning becomes more meaningful. It is important that students are given understanding and knowledge of environmental insight by building ecological intelligence, namely the ability of humans to adapt to the environment in which humans are located. It is important for humans to be able to innovate with their intelligence, awareness, ability and creativity to form a character of love for the environment. Every learning process that will be carried out, will definitely go through several processes or stages. They can be responsive and agile human beings in providing solutions to an environmental problem and benefit other humans.

Syahrul, et al. (2018) states that modules are basically teaching materials that are systematically arranged in language that is easily understood by students according to their level of knowledge and age, so they can be studied independently with a little help from 
educators. Learning modules are teaching materials designed by teachers. By designing modules, teachers can prepare learning carefully so that learning objectives can be achieved. Environmentally friendly Indonesian teaching materials can be developed by Indonesian language subject teachers with a group of other teachers in the KKG forum (Teacher Working Group). Syahrul, et al. (2021) suggest that to create an interesting, creative, efficient and innovative learning process, teachers must have the competence to choose teaching materials from various sources, using the latest learning tools; and use a variety of media to create fun learning. Indonesian language teaching materials developed by teachers can be in the form of digital writing, photos, videos, powerpoints, slide shows, music, digital sounds, and so on, which can be used as a means for teachers to educate and teach students directly or indirectly about language lessons. Indonesia is in accordance with the subject matter, as well as learning the character of love for the environment based on technology. Syahrul, et al. (2020) argues that the teacher's activities at this stage are to condition student learning readiness and provide an explanation of the learning activities that will be carried out. In particular, in using this learning model, the teacher has to ensure that all students prepare all the necessary learning devices such as computer or mobile devices, internet activation and so on. Training is needed to apply these teaching materials, Agusrida, et al. (2020) states that training is a process or method used to improve one's competence or competence in aspects of knowledge, skills, and attitudes that must be effective and efficient. In learning Indonesian, discourse materials (texts) with environmental themes are one of the a strategy to integrate environmental education that aims to form and develop a mindset and pattern of action, as well as healthy behavior both physically and mentally in life.

Developing teaching materials by prioritizing the values of environmental and spiritual insight, namely by downloading videos of various natural disasters, namely; earthquakes, hurricanes, tsunamis, floods, high tides, volcanic eruptions, falling meteors, etc. then collect them in a powerpoint slide. For example, one of the environmental insights in the teaching materials includes environmental awareness and maintaining cleanliness, to prevent flood disasters. The spiritual values in teaching materials are that every natural disaster there are verses from the Qur'an that discuss it. This certainly can increase students' faith in God Almighty and Almighty. Environmentally friendly Indonesian teaching materials are an alternative that can be chosen for effective and efficient learning media in creating a pleasant learning atmosphere for students. Indonesian language teaching materials that use digital technology facilities, without leaving and ignoring the character values of environmental insight. Technology may be used, but good morals and character must also accompany it. If good character has become part of the habits of students, of course it will be good for the people around them. 


\section{REFERENCES}

Agusrida, Atmazaki, Syahrul, R., \& Ermanto. (2020). Effectiveness of Online Scientific Publication Training Approach for Teacher's Professional Competence Development at Religious Training Center in Padang. 504(ICoIE), 370-375.

Mulyadi, M., Atmazaki A., \& R, S. (2019). The Development of Interactive MultimediaEModule on Indonesian Language Course. 178(IcoIE 2018), 291-295.

Novelti, N., Ramadhan, S., Ermanto, E., \& Agustina, A. (2018). Developing an Instructional Model Assisted Audio Visual Media. Iclle, 263, 111-116.

Syahrul, R. (2020). Effectiveness of Online Scientific Publication Training Approach for Teacher's Professional Competence Development at Religious Training Center in Padang. In 2nd International Conference Innovation in Education (ICoIE 2020), 370-375.

Syahrul, R., Atmazaki, Sukma, E., \& Indriyani, V. (2021). Multimedia with Social Learning Networks (SNL): As Learning Innovation in the 4.0 Industrial Era. Journal of Physics: Conference Series, 1779(1), 1-9.

Syahrul, R., Yasnur A., \& Vivi, I. (2018) Learning Module Design Writing Argumentative Text Based Problem-Based Learning, 263 (ICCLE 2018), 194-200.

Vivi, I., Atmazaki, Ramadhan, S. (2019). Literacy and Language Curriculum Innovation. Vol. 5, No. 1 108-118. 